\section{Role of NMDA receptors in the trigeminal pathway, and the modulatory effect of magnesium in a model of rat temporomandibular joint arthritis}

Cavalcante ALC, Siqueira RMP, Araujo JCB, Gondim DV, Ribeiro RA, Quetz JS, Havt A, Lima AAM, Vale ML. Role of NMDA receptors in the trigeminal pathway, and the modulatory effect of magnesium in a model of rat temporomandibular joint arthritis.

Eur J Oral Sci 2013; 121: 573-583. (C) 2013 Eur J Oral Sci

Temporomandibular joint (TMJ) arthritis is a common cause of orofacial pain. In the present study, the modulatory effects of $N$-methyl-D-aspartate receptors (NMDA-Rs) and magnesium were investigated in TMJ arthritis hypernociception. Male Wistar rats received an intra-articular injection of carrageenan $(\mathrm{Cg})$ in the TMJ, and mechanical hypernociception was measured. The NMDA-R antagonist, MK-801, and magnesium chloride $\left(\mathrm{MgCl}_{2}\right)$ were administered before arthritis induction. Magnesium deficiency was promoted by feeding rats a synthetic magnesium-free diet for $9 \mathrm{~d}$ before injection of $\mathrm{Cg}$. The $\mathrm{Cg}$ induced mechanical hypernociception that lasted for $120 \mathrm{~h}$. MK-801 inhibited this hypernociceptive state. $\mathrm{MgCl}_{2}$ pretreatment prevented $\mathrm{Cg}$-induced hypernociception and altered the nociceptive threshold in the absence of $\mathrm{Cg}$. Magnesium deficiency increased hypernociception and induced spontaneous hypernociceptive behavior. TMJ arthritis increased the expression of mRNA for all $N M D A-R$ subunits and immunostaining of phosphorylated NR1 (phospho-NR1). $\mathrm{MgCl}_{2}$ inhibited expression of NR2B mRNA and phosphoNR1 immunostaining and increased expression of NR3 mRNA. Magnesium deficiency increased expression of both NR1 and NR3 mRNAs and phospho-NR1 immunostaining in the trigeminal subnucleus caudalis. We found that magnesium modulates nociceptive behavior and induces $N M D A-R$ subunit rearrangement in the subnucleus caudalis. The present results may lead to a better understanding of central processing in the nociceptive trigeminal pathway and the development of new approaches to treat orofacial pain with a TMJ origin.
André L. C. Cavalcante ${ }^{1}$, Rafaelly M. P. Siqueira ${ }^{2}$, Joana C. B. Araujo $^{1}$, Delane V. Gondim ${ }^{3}$, Ronaldo A. Ribeiro' ${ }^{2}$, Josiane S. Quetz $^{4}$, Alexandre Havt ${ }^{2,4}$, Aldo A. M. Lima ${ }^{2,4}$, Mariana L. Vale ${ }^{1,2,3}$

${ }^{1}$ Medical Sciences Post-Graduation Program, Department of Clinical Medicine, Federal University of Ceará, Fortaleza;

${ }^{2}$ Pharmacology Post-graduation Program, Department of Physiology and Pharmacology, Federal University of Ceará, Fortaleza; ${ }^{3}$ Department of Morphology, Federal University of Ceará, Fortaleza; ${ }^{4}$ Institute of Biomedicine for Brazilian Semi-Arid \& Clinical Research Unit, Federal University of Ceara, Fortaleza, Brazil

Delane V. Gondim, Department of Morphology, Faculty of Medicine, Federal University of Ceará, R. Delmiro de Farias, s/n - Rodolfo Teófilo, Fortaleza, CE 60430-170, Brazil

E-mail: delanegondim@ufc.br

Key words: magnesium; $\mathrm{N}$-methyl-D-aspartate receptor (NMDA-R); NR3; orofacial pain; temporomandibular joint

Accepted for publication September 2013
Temporomandibular disorders (TMDs) are often related to chronic orofacial pain and are probably the most common non-tooth-related orofacial pain condition associated with a significant worsening of the patient's quality of life (1).

Temporomandibular disorders may be associated with the phenomenon of central and peripheral sensitization. Constant nociceptive input stimulus from the injured sites may result in excessive depolarization of the central nociceptive neurons, which can promote excitotoxicity and loss of inhibitory mechanisms and eventually provoke prolonged pain (2).

Some data show that excitatory amino acids (e.g. glutamate) and neuropeptides, through receptor mecha- nisms and involving mainly $N$-methyl-D-aspartate receptors (NMDA-Rs), have been implicated in these neuroplastic changes, enlarging receptor fields in the central nervous system for nociceptive input. $N$-methylD-aspartate receptors also play an essential role in the 'wind-up' phenomenon of central sensitization mediated by the trigeminal brainstem sensory nuclear complex (3-8)

$\mathrm{N}$-methyl-D-aspartate receptors play an essential role in these nociceptive processes, and NMDA-R antagonists or modulators may be useful in the treatment of persistent pain in the temporomandibular joint (TMJ) area $(7,9-16)$

Magnesium is a natural modulator of NMDA-Rs, functioning as a physiological channel blocker that 
reduces ion currents (17). Magnesium is also a calcium antagonist in some systems, reducing neuronal excitability and neurotransmitter release (17-19). The depolarization process removes the magnesium-induced blockade of NMDA-Rs in a voltage-dependent manner, resulting in hyperexcitability and consequently a sustained state of depolarization and increased synaptic strength $(17,19,20)$.

$N$-methyl-D-aspartate receptors are composed of the NR1, NR2, and NR3 subunits. The combination of NR1, an essential channel-forming subunit, with the other subunits can change the kinetics of receptor depolarization and sensitivity to magnesium-induced blockade and calcium entry $(16,17)$. Some gene-expression studies showed the differential expression of these subunits according to different stimulation that reaches the central nervous system through the trigeminal pathway (21-23), but no evidence has been provided on the regulatory mechanism of magnesium in NMDA-R subunit expression in trigeminal subnuclei.

Considering the sparse evidence on the importance of NMDA-Rs in acute and chronic orofacial pain, and the possibility that magnesium can modulate NMDA-R responses in orofacial pain, we aimed to highlight the role of these receptors in the hypernociceptive process in the TMJ region. Additionally, the present study investigated the role of magnesium in the nociceptive response and NMDA-R gene expression in rats with TMJ arthritis.

\section{Material and methods}

\section{Animals}

We used male Wistar rats that weighed 180-200 $\mathrm{g}$ and were housed in a temperature-controlled room $\left(22^{\circ} \mathrm{C}\right)$. The experimental protocol was approved by the Animal Ethics Committee of the Faculty of Medicine, Federal University of Ceará (protocol no. 30/10) and was performed in accordance with the Guide for the Care and Use of Laboratory Animals. Efforts were made to use the smallest number of rats possible and to minimize the stress to which they were subjected.

\section{Drugs and reagents}

Carrageenan (Cg), MK-801, and tribromoethanol were purchased from Sigma-Aldrich (St Louis, MO, USA). Magnesium chloride $\left(\mathrm{MgCl}_{2}\right)$ (Vetec, Rio de Janeiro, Brazil) was diluted in mineral water. PCR primers were purchased from Invitrogen (San Diego, CA, USA). The immunohistochemistry ABC kit was obtained from Santa Cruz Biotechnology (Santa Cruz, CA, USA).

\section{Experimental model}

Joint inflammation was induced by an intra-articular injection of $\mathrm{Cg}(5 \%$ or $500 \mu \mathrm{g}$ per articulation; $10 \mu \mathrm{l}$ volume). A $5 \% \mathrm{Cg}$ solution $(10 \mu \mathrm{l})$ in sterile saline was injected into the supradiscal space of the left TMJ (ipsilateral) using a microsyringe (Hamilton model 702RN; Hamilton, Reno,
NV, USA) coupled to a 30-gauge gingival needle (BD, Franklin Lakes, NJ, USA). As a control procedure, another group of rats was injected intra-articularly with saline unilaterally in the left joint.

Before injection with $\mathrm{Cg}$ or saline, the rat was anesthetized with tribromoethanol, and the TMJ skin region was carefully shaved. The posteroinferior border of the zygomatic arch was palpated, and the needle was inserted inferior to this point and advanced in a medial and anterior direction until the needle made contact with the condyle. This contact was verified by moving the mandible, and the puncture of the needle into the joint space was confirmed by the loss of resistance. Gentle aspiration excluded intravascular placement, after which the specified volume of $\mathrm{Cg}$ or saline was injected.

Mechanical hypernociception in the TMJ was evaluated by measuring the threshold of force intensity, in grams, needed to be applied to the TMJ region until a reflex response of the rat occurred (e.g. head-withdrawal or vocalization). The measurements were performed by an examiner unaware of the treatments, making use of a digital device (Insight; Ribeirão Preto, SP, Brazil). Each rat was housed individually in a plastic cage, $30 \mathrm{~min}$ before beginning the tests, and was subjected to a conditioning session of headwithdrawal threshold measurements in the test room for three consecutive days under controlled temperature and low illumination and noise. On the $3 \mathrm{rd} \mathrm{d}$, the basal force threshold value was recorded before intra-articular injection of either $\mathrm{Cg}$ or vehicle. The measurement of force thresholds was performed (in triplicate) from the ipsilateral TMJ, 4, 6, $12,24,48,72$, and $168 \mathrm{~h}$ after injection of $\mathrm{Cg}(24)$. For each experiment, the nociceptive threshold was assessed before the induction of arthritic hypernociception to determine baseline values before the treatment induction when hypernociception developed (i.e. control values) and then once per day after injection of $\mathrm{Cg}$.

\section{Trigeminal spinal nuclei extraction: subnucleus caudalis region}

Six, 24, 72, and $120 \mathrm{~h}$ after injection of $\mathrm{Cg}$ into the TMJ, the rats were anesthetized with an intraperitoneal injection of $2.5 \%$ tribromoethanol $\left(250 \mathrm{mg} \mathrm{kg}^{-1}\right)$ and transcardially perfused with $4 \%$ paraformaldehyde in $0.1 \mathrm{M}$ phosphate buffer ( $\mathrm{pH}$ 7.4).

The brain and brainstem were quickly removed, and the trigeminal nuclei area was dissected, postfixed in $4 \%$ formalin for $60-90 \mathrm{~min}$, then sliced into longitudinal $10-\mu \mathrm{m}$ slices for the immunohistochemistry assay.

Other groups of rats were anesthetized with an intraperitoneal injection of tribromoethanol $\left(0.03 \mathrm{mg} \mathrm{kg}^{-1}\right)$ and decapitated. The brain and brainstem were quickly removed, and the trigeminal nuclei area was dissected, immediately frozen in liquid nitrogen, and kept frozen at $-80^{\circ} \mathrm{C}$ until further processing for real-time PCR. The sections used in this study were cut -10.5 to $-14.04 \mathrm{~mm}$ from the bregma (25).

\section{Induction of magnesium deficiency in rats}

The rats were randomly divided into two groups: normal and magnesium-deficient. The magnesium-deficient groups were allowed to feed for $9 \mathrm{~d}$ ad libitum on a synthetic magnesiumfree diet. Deionized water was provided ad libitum during the same period. The synthetic magnesium-free diet contained 
cornstarch (397 $\left.\mathrm{g} \mathrm{kg}^{-1}\right)$, casein $\left(200 \mathrm{~g} \mathrm{~kg}^{-1}\right)$, sucrose $\left(100 \mathrm{~g} \mathrm{~kg}^{-1}\right)$, soybean oil $\left(70 \mathrm{~g} \mathrm{~kg}^{-1}\right)$, fiber $\left(50 \mathrm{~g} \mathrm{~kg}^{-1}\right)$, Lcystine $\left(3 \mathrm{~g} \mathrm{~kg}^{-1}\right)$, choline bitartrate $\left(2.5 \mathrm{~g} \mathrm{~kg}^{-1}\right)$, AIN$93 \mathrm{VX}$ vitamin mix $\left(10 \mathrm{~g} \mathrm{~kg}^{-1}\right)$, and magnesium-free mineral mix (35 g kg-1; AIN93 magnesium free; Rhoster, São Paulo, Brazil). After the 9th $\mathrm{d}$, the rats received an intra-articular injection of $\mathrm{Cg}$ in the left TMJ and continued to feed on the special diet for five more days.

The assessment of head-withdrawal thresholds (mechanical hypernociception) was performed before beginning the special diet and was repeated after $9 \mathrm{~d}$ of feeding on this diet. The control group was fed a normal diet and was also subjected to the same conditions as the rats that received the special diet.

To verify magnesium deficiency, serum magnesium concentrations were determined before and after $9 \mathrm{~d}$ of special diet feeding, as described below.

\section{Magnesium supplementation}

Magnesium supplementation was implemented with oral administration of $\mathrm{MgCl}_{2}$ dissolved in mineral water. We tested dosages of 10,30 , and $90 \mathrm{mg} \mathrm{kg}^{-1}$ per day, administered orally in a volume of $0.5 \mathrm{ml}$ twice per day for 3,5 , and $7 \mathrm{~d}$ before the injection of $\mathrm{Cg}$. The treatment was continued after injection with $\mathrm{Cg}$ until the 7 th $\mathrm{d}$.

\section{Determination of serum magnesium}

The rats were anesthetized with $2.5 \%$ tribromoethanol (250 mg kg-1 of body weight, intraperitoneally). Blood was collected from the orbital venous plexus into heparinized tubes. Serum samples were obtained after low-speed centrifugation (1125 $g$ for $15 \mathrm{~min})$. A standardized diagnostic kit for magnesium determination (Labtest Diagnóstica, Minas Gerais, Brazil) was used. The spectrophotometric determination of serum magnesium was performed at $540 \mathrm{~nm}$, as determined by the kit's manufacturer.

\section{Drug treatment}

Pharmacological blockade of NMDA-Rs was performed with a single intraperitoneal administration of the NMDA receptor antagonist, MK-801 $\left(0.1,0.25\right.$, and $\left.0.5 \mathrm{mg} \mathrm{kg}^{-1}\right)$, $30 \mathrm{~min}$ before injection with $\mathrm{Cg}$. The nociceptive threshold was measured before, and 4, 6, 10, 24, and $168 \mathrm{~h}$ after, injection of $\mathrm{Cg}$.

\section{Total RNA isolation}

The adult rat brainstem, dissected in the region of the trigeminal subnucleus caudalis, was obtained as described above. The average quantity of tissue isolated from each rat sample was approximately $100 \mathrm{mg}$. The tissues were weighed and stored at $-80^{\circ} \mathrm{C}$ until used for the analysis. Total RNA was isolated from each sample using the RNeasy Mini kit (Qiagen, Valencia, CA, USA) according to the manufacturer's instructions. Briefly, sample grinding was performed with QIAzol lysis reagent (Qiagen) using a cell disruptor composed of a rotary tool (Dremel 300-N/10; Racine, WI, USA.) and autoclavable steel rotating blades (in-house design). After membrane disruption and release of nucleic acid into the medium, the solution was centrifuged at $20,000 \mathrm{~g}$ for $5 \mathrm{~min}$, and $200 \mu \mathrm{l}$ of 1-bromo-3-chloropropane (BCP; Fluka, Milwaukee, WI, USA) was added to the supernatant. After homogenization and centrifugation at $15,000 \mathrm{~g}$ for $15 \mathrm{~min}$ at $4^{\circ} \mathrm{C}$, the $2-\mathrm{ml}$ tube contents were separated into three phases, and the impure RNA was found in the upper limpid phase. The following steps consisted of assembling the impure RNA in a spin column to remove impurities using 70\% ethanol and RW1 and RPE buffers (Qiagen). The elution of highly pure nucleic acids occurs in RNase-free water. The RNA obtained was quantified using NanoDrop (Thermo Fisher Scientific, Waltham, MA, USA).

\section{Reverse transcription reaction}

To evaluate the gene expression of NR1 (NMDA1), NR2B (NMDA2B), and NR3 (NMDA3), the isolated RNA was transformed to cDNA by a reverse transcription reaction using a SuperScript III Reverse Transcriptase System (Invitrogen). Briefly, RNA samples $(1 \mu \mathrm{g})$ were incubated with $4 \mu \mathrm{l}$ of $5 \times$ iScript Reaction Mix and $1 \mu \mathrm{l}$ of iScript Reverse Transcriptase (Bio-Rad, Hercules, CA, USA) in Milli-Q water to a final volume of $20 \mu \mathrm{l}$. This reaction was cycled at $25^{\circ} \mathrm{C}$ for $5 \mathrm{~min}, 42^{\circ} \mathrm{C}$ for $30 \mathrm{~min}$, and $85^{\circ} \mathrm{C}$ for $5 \mathrm{~min}$. The synthesized cDNA was kept in a freezer at $-20^{\circ} \mathrm{C}$ until amplification by real-time quantitative PCR (qPCR).

\section{Real-time qPCR}

The expression of NMDA-1, NMDA-2, and NMDA-3 genes was assayed using an iQ5 Real-Time PCR Detection System (Bio-Rad), based on the detection of SYBR Green

Table 1

Oligonucleotide sequence of primers used in the qPCR assays

\begin{tabular}{|c|c|c|c|c|}
\hline Gene & Target & Primer sequence $\left(5^{\prime}-3^{\prime}\right)$ & $\begin{array}{l}\text { Product } \\
\text { size (bp) }\end{array}$ & $\begin{array}{l}\text { Accession no. } \\
\text { (GenBank, NCBI) }\end{array}$ \\
\hline YHAWZ & $\begin{array}{l}\text { Rattus norvegicus tyrosine 3-monooxygenase/ } \\
\text { tryptophan 5-monooxygenase activation } \\
\text { protein }\end{array}$ & $\begin{array}{l}\text { F- GCTACTTGGCTGAGGTTGCT } \\
\text { R- TGCTGTGACTGGTCCACAAT }\end{array}$ & 61 & NM_013011.3 \\
\hline NMDAR-1 & $\begin{array}{l}\text { Rattus norvegicus NMDAR1 glutamate receptor } \\
\text { subunit }\end{array}$ & $\begin{array}{l}\text { F- GCAGAACGTTTCCCTGTCCA } \\
\text { R- CCCCTGCCATGTTCTCAAAA }\end{array}$ & 140 & U11418.1 \\
\hline NMDAR-2 & $\begin{array}{l}\text { Rattus norvegicus NMDAR glutamate receptor } \\
\text { subtype } 2 \mathrm{C}\end{array}$ & $\begin{array}{l}\text { F- ATGGCGGGGGTCTTCTACAT } \\
\text { R- GTCCAGCTGGGATGAGTTGG }\end{array}$ & 120 & M91563.1 \\
\hline NMDAR-3 & $\begin{array}{l}\text { Rattus norvegicus NMDAR3 glutamate receptor } \\
\text { subunit }\end{array}$ & $\begin{array}{l}\text { F- TTCATGTGGCCACTCCACTG } \\
\text { R- CCAAAGGGGCTCTTCCATTC }\end{array}$ & 101 & AF073379.1 \\
\hline
\end{tabular}

NMDAR, N-Methyl-D-Aspartate Receptor; F, forward primer; R, reverse primer. 
incorporation. Phospholipase A2 (tyrosine 3-monooxygenase/tryptophan 5-monooxygenase activation protein zeta polypeptide) was used as the reference gene (YHWAZ). DNA primers for all of the genes (Table 1) were designed on the basis of mRNA sequences obtained from the National Center for Biotechnology Information (http:// www.ncbi.nlm.nih.gov; accessed December 26, 2011). Real-time PCR assays were performed in a final volume of $25 \mu \mathrm{l}$ of a medium that contained $12.5 \mu \mathrm{l}$ of iQ SYBR Green Supermix (a standard buffer for amplification containing reagents, such as DNA polymerase, deoxynucleotide triphosphates (dNTPs), and saline buffer, at optimal concentrations for RT-PCR assays), $200 \mathrm{nM}$ primers, and $2 \mu \mathrm{l}$ of cDNA of the samples. Negative samples were also tested, in which the cDNA was replaced with autoclaved Milli-Q water. The PCR conditions were as follows: an initial denaturation step of $7 \mathrm{~min}$ at $95^{\circ} \mathrm{C}$, followed by 40 cycles for gene amplification. Each cycle consisted of an initial denaturation phase of $30 \mathrm{~s}$ at $95^{\circ} \mathrm{C}$, followed by an annealing phase of $30 \mathrm{~s}$ at $61^{\circ} \mathrm{C}$ and an extension phase of $45 \mathrm{~s}$ at $72^{\circ} \mathrm{C}$. The samples were then subjected to an extension step of $3 \mathrm{~min}$ at $72^{\circ} \mathrm{C}$. To ensure the specificity of the amplifications applied (i.e. to determine whether the products formed were specific for the tested genes), we constructed a melting curve after each reaction, in which the reaction temperature was subsequently increased by $0.5^{\circ} \mathrm{C}$ every $20 \mathrm{~s}$, beginning at the annealing temperature of a given primer and ending at $95^{\circ} \mathrm{C}$. Throughout the $\mathrm{qPCR}$ amplification process, changes in fluorescence were measured, and the data obtained from iQ5 Optical System software (version 2.0; Bio-Rad) were based on the values of the threshold cycle, in which the observed fluorescence is 10-fold higher than the basal fluorescence for each PCR assay. Gene expression was obtained by applying the mathematical method of PfAFfL (26).

\section{Immunohistochemistry}

Immunohistochemistry for phosphorylated NR1 was performed using the streptavidin-biotin-peroxidase method in formalin-fixed, paraffin-embedded tissue sections $(5 \mu \mathrm{m}$ thick) mounted on poly-L-lysine-coated microscope slides. The sections were deparaffinized and rehydrated using xylene and a graded series of alcohol. After antigen retrieval with citrate buffer $(\mathrm{pH} 6.0)$ at $95^{\circ} \mathrm{C}(15 \mathrm{~min})$, endogenous peroxidase was blocked twice $(10 \mathrm{~min})$ with $3 \%(\mathrm{v} / \mathrm{v})$ hydrogen peroxide and washed in PBS. The sections were incubated overnight at $4^{\circ} \mathrm{C}$ with primary rabbit anti-(phospho-NR1) (Millipore, São Paulo, Brazil), diluted 1:200 in PBS containing 5\% BSA (PBS/BSA). The slides were then incubated with biotinylated goat anti-rabbit (Santa Cruz Biotechnology) diluted 1:400 in PBS/BSA. After washing, the slides were incubated with avidin-biotin-horseradish peroxidase conjugate (Strep ABC complex; Santa Cruz Biotechnology) for 30 min according to the manufacturer's protocol. Immunostaining was visualized with the chromogen 3,3'-diaminobenzidine (DAB; $\mathrm{ABC}$ staining system; Santa Cruz Biotechnology). Negative control sections were processed simultaneously, as described above, but with the first antibody replaced with PBS/BSA. None of the negative controls showed immunoreactivity to phospho-NR1. The slides were counterstained with Mayer's hematoxylin, dehydrated in a graded series of alcohol, cleared in xylene, and coverslipped. Each group consisted of six rats. Positive labeling for phospho-NR1 was determined by brown staining.
The slides were photographed with a Leica microscope coupled with a DFC232 camera (Leica, Wetzlar, Germany). After focusing the microscope, the left Sp5C area was identified and photographed at $200 \times$ magnification.

The area stained in the pictures was quantified by differentiating the areas (pixels) with higher color saturation associated with immunostaining (brown). For this, we used the IMAGE J-NIH software (http://rsb.info.nih.gov). The procedure was based on color saturation associated with positive staining for a particular marker. The limits required for defining selected pixels were previously defined by color threshold. The percentage of the area stained in each photograph was calculated by dividing the selected pixel areas by the total area of the photograph. At least four photographs per group were evaluated.

\section{Statistical analysis}

The results are expressed as the mean \pm standard error of the mean of the measurements from at least six rats per group. ANOVA followed by Bonferroni's test was used to compare means. The Student's $t$-test was used to compare two means. Values of $P<0.05$ were considered statistically significant.

\section{Results}

\section{Time-course of the hypernociceptive effect}

The intra-articular $\mathrm{Cg}$ injection resulted in time-dependent and long-term hypernociception in response to mechanical stimulation, measured by a marked decrease in the mechanical head-withdrawal threshold. The mechanical hypernociception induced by $\mathrm{Cg}$ began at the 4-h time-point, peaked between 6 and $12 \mathrm{~h}$ $(P<0.001)$, with the peak lasting until $96 \mathrm{~h}(P<0.05)$, and had returned to baseline by $168 \mathrm{~h}$. The rats injected with intra-articular saline in the left TMJ presented no significant changes in mechanical withdrawal thresholds at any of the time-points evaluated (Fig. 1).

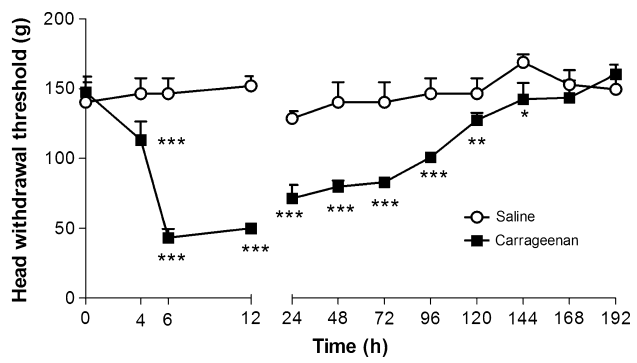

Fig. 1. Time course of the hypernociceptive effect of carrageenan-induced temporomandibular joint (TMJ) arthritis. Saline $(10 \mu \mathrm{l})$ or $5 \%$ carrageenan $(10 \mu \mathrm{l})$ was injected intraarticularly into the left TMJ of rats. The nociceptive threshold (head withdrawal) in response to mechanical stimulation was measured before and after (4-192 h) the injection. The data are expressed as the mean \pm standard error of the mean of the force threshold, in grams, of six rats per group. Asterisks indicate significant differences from the saline group (Student's $t$-test; $* * * P<0.001, * * P<0.01, * P<0.05$ ). 


\section{Effect of NMDA-R antagonist}

We investigated the role NMDA-Rs in the nociceptive effect of Cg-induced TMJ arthritis. The effect of the nonselective NMDA-R antagonist, MK-801, was investigated at doses of $0.1,0.25$, and $0.5 \mathrm{mg} \mathrm{kg}^{-1}$, intraperitoneally. Our results showed that 0.25 and $0.5 \mathrm{mg} \mathrm{kg}^{-1}$ of MK-801 dose-dependently increased mechanical withdrawal thresholds compared with the control group (Fig. 2). Four hours after injection with $\mathrm{Cg}$, no significant effect of MK-801 was observed compared with the control group. Withdrawal thresholds were increased by treatment with MK-801 only, starting at $6 \mathrm{~h}$ (i.e. the peak of hypernociception; $P<0.001)$ and remained at levels significantly different from controls up to $144 \mathrm{~h}(P<0.05)$. The dose of $0.5 \mathrm{mg} \mathrm{kg}^{-1}$ had a maximum inhibitory effect among treated groups, at $48 \mathrm{~h}(P<0.001)$, that lasted until 120 h $(P<0.05)$ after injection with $\mathrm{Cg}$.

\section{Effect of oral $\mathrm{MgCl}_{2}$ supplementation}

An experiment was first designed to determine the dose at which $\mathrm{MgCl}_{2}$ would exert an antihypernociceptive effect. We tested doses of 10 , 30, and $90 \mathrm{mg} \mathrm{kg}^{-1}$ (given twice per day; 3-d pretreatment). The results showed that the $90-\mathrm{mg} \mathrm{kg}^{-1}$ dose inhibited hypernociception 4, 6, 24, and 120-168 h after injection with $\mathrm{Cg}$, reaching the maximal effect at $6 \mathrm{~h}(P<0.001)$. Interestingly, we found that after $3 \mathrm{~d}$ of treatment with $90 \mathrm{mg} \mathrm{kg}{ }^{-1}$ of $\mathrm{MgCl}_{2}$, withdrawal thresholds were significantly increased $(P<0.01)$, even before injection with $\mathrm{Cg}$, compared with the non-treated group (Fig. 3).

We then evaluated the time-course of the effect of $90 \mathrm{mg} \mathrm{kg}{ }^{-1}$ of $\mathrm{MgCl}_{2}$ over 5 and $7 \mathrm{~d}$ of pretreatment. Our results showed a progressive increase in withdrawal thresholds with 5 and $7 \mathrm{~d}$ of treatment. Withdrawal thresholds were significantly higher at all time-points evaluated after administration of $\mathrm{Cg}(P<0.001$; Fig. 4A,B $)$.

To verify whether plasma magnesium concentrations increased in rats supplemented with $\mathrm{MgCl}_{2}$, we determined the serum magnesium concentrations 3, 5, and $7 \mathrm{~d}$ after starting $\mathrm{MgCl}_{2}$ supplementation, before injection with $\mathrm{Cg}$. Plasma magnesium levels were significantly increased in all groups treated with $\mathrm{MgCl}_{2}$ $(P<0.05)$ compared with baseline serum magnesium levels (Fig. 4C).

\section{Effect of magnesium deficiency}

Nine days after starting the magnesium-free diet, the rats showed a significant decrease in head-withdrawal thresholds $(P<0.001)$ compared with the normal diet group (Fig. 5B). Head-withdrawal thresholds were assessed before injection of $\mathrm{Cg}$. Plasma magnesium levels were also assessed. After $9 \mathrm{~d}$ of the special diet, the rats displayed a significant decrease in plasma magnesium concentrations compared with rats receiving the normal diet $(P<0.001$; Fig. 5A).

Four hours after injection of $\mathrm{Cg}$, a significant difference $(P<0.001)$ was observed between the group treated

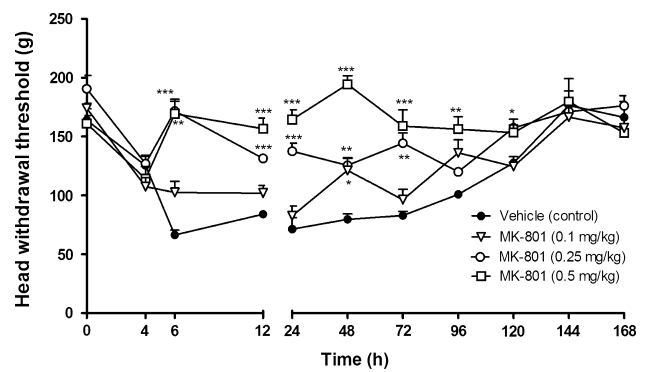

Fig. 2. Evaluation of the antinociceptive effect of the $N$ methyl-D-aspartate receptor (NMDA-R) antagonist, MK-801, in carrageenan-induced temporomandibular joint (TMJ) arthritis. MK-801 $\left(0.1,0.25\right.$, or $\left.0.5 \mathrm{mg} \mathrm{kg}^{-1}\right)$ or vehicle (control) was injected intraperitoneally $30 \mathrm{~min}$ before the intraarticular injection of $5 \%$ carrageenan $(10 \mu \mathrm{l})$ into the left TMJ. The nociceptive threshold (head withdrawal) in response to mechanical stimulation was measured before and after (4 $168 \mathrm{~h}$ ) the injection. The data are expressed as the mean \pm standard error of the mean of the force threshold, in grams, of six rats per group. Asterisks indicate significant differences from vehicle (ANOvA followed by Bonferroni's test; $* * * P<0.001, * * P<0.01, * P<0.05)$.

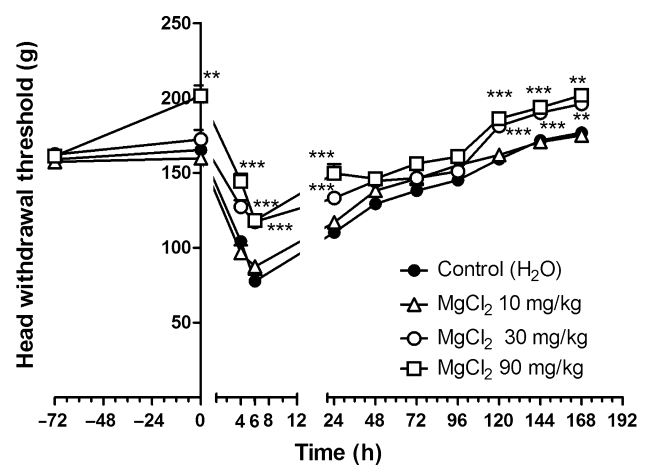

Fig. 3. Antinociceptive effect of magnesium chloride $\left(\mathrm{MgCl}_{2}\right)$ in carrageenan-induced temporomandibular joint (TMJ) arthritis. Vehicle $\left(\mathrm{H}_{2} \mathrm{O}\right)$ or $\mathrm{MgCl}_{2}\left(10,30\right.$, or $\left.90 \mathrm{mg} \mathrm{kg}^{-1}\right)$ was administered orally, twice daily (at 12-h intervals) for $3 \mathrm{~d}$, before intra-articular injection of $5 \%$ carrageenan $(10 \mu \mathrm{l})$ into the left TMJ and also until day 168. The nociceptive threshold (head withdrawal) in response to mechanical stimulation was measured before and after $(4-168 \mathrm{~h})$ the injection. The data are expressed as the mean \pm standard error of the mean of the force threshold, in grams, of six rats per group. Asterisks indicate significant differences from vehicle (ANOvA followed by Bonferroni's test; $* * * P<0.001, * * P<0.01$ ).

with a normal diet and the group treated with the magnesium-free diet; this difference lasted for $6 \mathrm{~h}$ (maximum effect, $P<0.001)$ and had disappeared by the 24 -h time point. Interestingly, $96 \mathrm{~h}(P<0.05)$ after injection of $\mathrm{Cg}$, a difference between these groups reappeared that remained until the 120 -h time point $(P<0.001)$.

Treatment with MK-801 prevented the decrease in head-withdrawal thresholds induced by magnesium deficiency in $\mathrm{Cg}$ - and saline-injected rats $(P<0.001)$ The inhibition induced by MK- 801 reached $100 \%$ $(P<0.001)$ of the hypernociceptive effect of $\mathrm{Cg}$ and magnesium deficiency. 

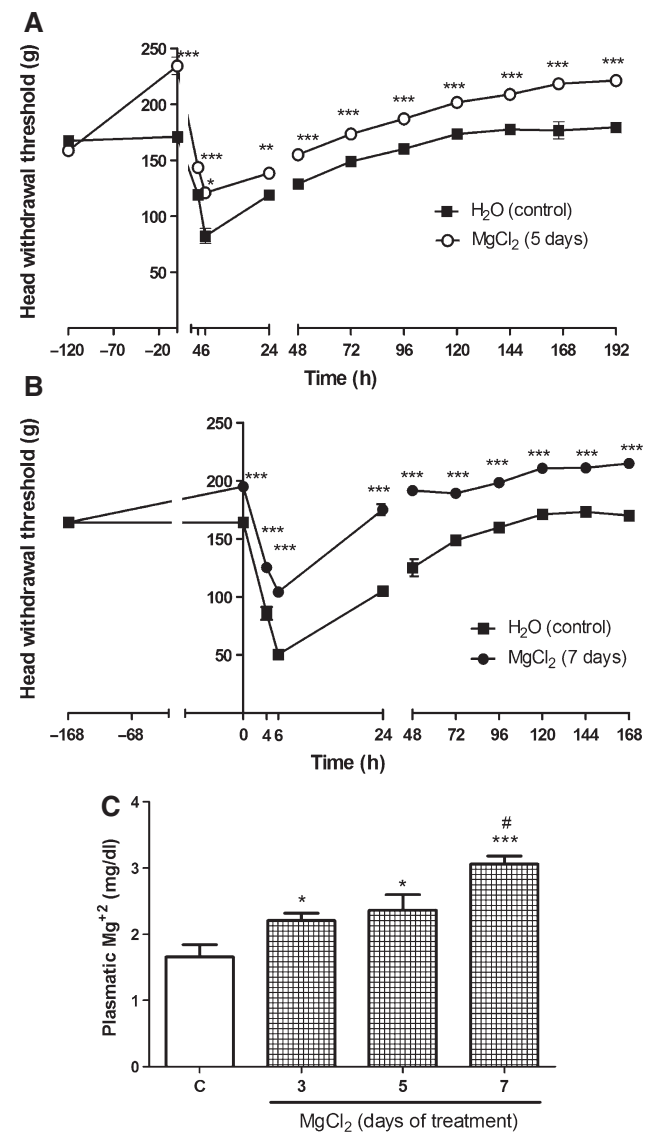

Fig. 4. Time-course of the antinociceptive effect of magnesium chloride $\left(\mathrm{MgCl}_{2}\right)$ in carrageenan-induced temporomandibular joint (TMJ) arthritis. Vehicle (V; $\left.\mathrm{H}_{2} \mathrm{O}\right)$ or $\mathrm{MgCl}_{2}$ $\left(90 \mathrm{mg} \mathrm{kg}^{-1}\right.$ ) was administered orally, twice daily (at 12-h intervals) for (A) $5 \mathrm{~d}$ and (B) $7 \mathrm{~d}$, before intra-articular injection of $5 \%$ carrageenan $(10 \mu \mathrm{l})$ into the left TMJ and also until day 168. The nociceptive threshold (head withdrawal) in response to mechanical stimulation was measured before and after $(4-168 \mathrm{~h})$ the injection. The data are expressed as the mean \pm standard error of the mean of the force threshold, in grams, of six rats per group. Asterisks indicate significant differences compared with the vehicle group (ANOvA followed by Bonferroni's test; ${ }^{* * *} P<0.001,{ }^{* *} P<0.01,{ }^{*} P<0.05$ ). (C) Animals were treated with vehicle $(\mathrm{V})$ or magnesium chloride $\left(\mathrm{MgCl}_{2} ; 90 \mathrm{mg} \mathrm{kg}^{-1}\right.$; twice daily (at 12-h intervals)). The results are expressed as the mean \pm standard error of the mean of plasma magnesium $\left(\mathrm{Mg}^{2+} ; \mathrm{mg} \mathrm{dl}^{-1}\right.$ of blood) levels. Asterisks indicate significant differences compared with the vehicle group $(t$-test; $95 \% \mathrm{CI} ; * * * P<0.001, * * P<0.01$, ${ }^{*} P<0.05 ;{ }^{\#} P<0.05$, day $5 \times 7$ treatment day interaction).

\section{NMDA-R gene expression in rat trigeminal subnucleus caudalis}

Expression of the genes encoding three $N M D A-R$ subunits was investigated in tissue samples obtained from the trigeminal subnucleus caudalis. NMDAR1 (NR1), NMDAR2B (NR2B), and NMDAR3 (NR3) were expressed (Figs 6 and 7), and their expression profiles changed according to $\mathrm{MgCl}_{2}$ treatment, magnesium deficiency, and Cg-induced TMJ inflammation (arthritis).

Carrageenan-induced arthritis in the TMJ significantly increased expression of the NR1 subunit
$(P<0.05)$ compared with naive rats. Treatment with $\mathrm{MgCl}_{2}$ did not modify expression of the NR1 subunit compared with the non-treated group but still induced a significant difference compared with the naive group $(P<0.05$; Fig. 6A) .

No difference in expression of the NR2B subunit was found between naive rats and rats in the $\mathrm{Cg}$-induced arthritis group. A decrease in expression of the NR2B subunit was found in arthritic rats treated with $\mathrm{MgCl}_{2}$ compared with rats in the naive group $(P<0.05$; Fig. 6B) and in the non-treated group $(P<0.05$; data not shown).

Expression of the NR3 subunit was weak but significantly increased in the Cg-induced arthritis group compared with naive rats $(P<0.05$; Fig. 6C), and treatment with $\mathrm{MgCl}_{2}$ resulted in a two-fold increase in expression of the NR3 subunit $(P<0.05$; Fig. 6C). A two-fold increase in expression of the NR3 subunit was also observed when the treated rats were compared with non-treated arthritic rats $(P<0.05$; data not shown).

Magnesium deficiency significantly increased expression of the NR1 subunit $(P<0.05)$ compared with naive rats (Fig. 7A). When TMJ arthritis was induced by $\mathrm{Cg}$ in magnesium-deficient rats, expression of the NR1 subunit decreased compared with that in the naive group $(P<0.05$; Fig. 7A) and in the magnesium-deficient group not injected with $\mathrm{Cg}(P<0.05$; data not shown). In summary, treatment of magnesium-deficient rats with $\mathrm{Cg}$ decreased expression of the NR1 subunit.

Magnesium deficiency did not modify NR2B expression in either arthritic or non-arthritic rats (Fig. 7B). Expression of the NR3 subunit was significantly upregulated in magnesium-deficient rats $(P<0.05)$, with no differences found between $\mathrm{Cg}$-treated and nontreated rats (Fig. 7C).

\section{Immunohistochemistry for NR1 subunit phosphorylation}

The immunohistochemical analysis showed an increase in phosphorylation of the NR1 subunit (phospho-NR1) in the subnucleus caudalis region in rats with Cg-induced arthritis $(P<0.001)$ compared with naive rats (Fig. 8B,C,G). Treatment with $\mathrm{MgCl}_{2}$ decreased $(P<0.05)$ this immunostaining (Fig. 8D,G) compared with $\mathrm{Cg}$-treated rats. Magnesium deficiency also increased $(P<0.001)$ phospho-NR1 immunostaining in both the saline- and $\mathrm{Cg}$-treated groups (Fig. 8E-G).

\section{Discussion}

A previous study showed that a single $\mathrm{Cg}$ injection caused a persistent hypernociceptive response. Our results showed that $\mathrm{Cg}$-induced orofacial hypernociception lasted until day 6. After this point, the withdrawal threshold was almost equal to baseline (24).

To understand, in more detail, the central processing of arthritic TMJ hypernociception via the trigeminal pathway, we examined the role of NMDA-Rs in the subnucleus caudalis region. MK-801, a specific antago- 

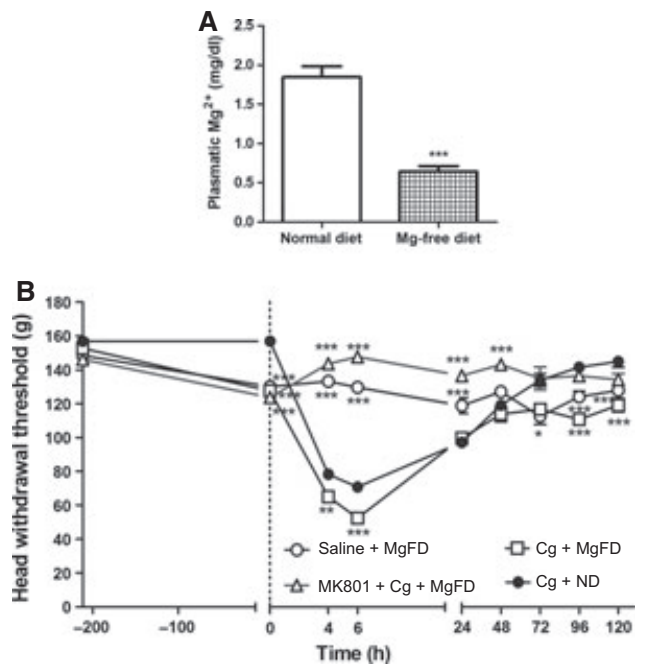

Fig. 5. Hypernociceptive effect of magnesium deficiency in carrageenan-induced temporomandibular joint (TMJ) arthritis. A special magnesium-free diet was administered for $9 \mathrm{~d}$ before treatment with carrageenan and during all other days of the experiment. Plasma magnesium levels in rats that were fed the normal diet (ND) and magnesium-free diet (MgFD) were measured after $9 \mathrm{~d}$ (A). MK-801 $\left(0.5 \mathrm{mg} \mathrm{kg}^{-1}\right)$ was administered $30 \mathrm{~min}$ before intra-articular injection of $5 \%$ carrageenan $(\mathrm{Cg} ; 10 \mu \mathrm{l})$ into the left TMJ (B). The nociceptive threshold was measured in response to mechanical stimulation before and after $(4-120 \mathrm{~h})$ the intra-articular injection of carrageenan. The results are expressed as the mean \pm standard error of the mean plasma magnesium $\left(\mathrm{Mg}^{2+} ; \mathrm{mg} \mathrm{dl}^{-1}\right.$ of blood) levels (A) or the threshold of force, in grams (B). Asterisks indicate significant differences from the $\mathrm{Cg}+\mathrm{ND}$ group (ANOVA followed by Bonferroni's test; $* * * P<0.001$, $* * P<0.01, * P<0.05)$

nist, completely reduced ongoing hypernociceptive behavior related to arthritic TMJ and oral $\mathrm{MgCl}_{2}$ supplementation. Furthermore, the MK-801-induced blockade of hypernociception had a long-lasting effect of up to $120 \mathrm{~h}$ after a single injection.

The same doses used in our study rapidly and robustly reduced mechanical and thermal hypernociception in neuropathic models in previous studies $(9,12)$.

Magnesium is a physiological NMDA-R modulator that plays a significant role in the blockade of glutamate-induced channel opening $(19,21,22)$. We investigated the effect of magnesium supplementation and magnesium deficiency in hypernociceptive processing in the trigeminal pathway. Previous studies demonstrated that magnesium deficiency sensitized nociceptive pathways in the spinal cord, with the involvement of both NMDA and non-NMDA receptors $(9,27)$. Magnesium supplementation decreased the effect of excitatory amino acids in the central nervous system (28).

Our data showed that repeated administration of $\mathrm{MgCl}_{2}$ partially reversed mechanical hypernociception in an animal model of TMJ arthritis. Other authors who used different experimental models found similar results using $\mathrm{MgSO}_{4}(27,29)$.

In the present study, on day 7 , plasma magnesium levels were approximately $1.1 \mathrm{mM}$ in the $\mathrm{MgCl}_{2}$-treated group, below toxic levels. Considering that no rigid
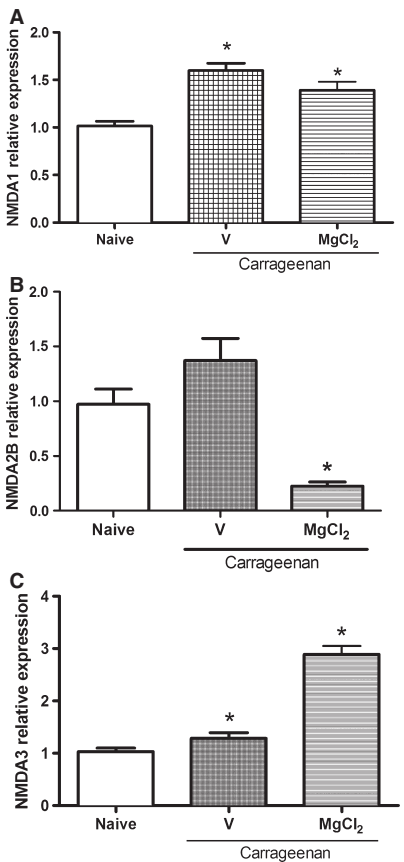

Fig. 6. Relative quantitative mRNA expression of the $\mathrm{N}$ methyl-D-aspartate receptors (NMDA-Rs) NR1 (NMDA1), NR2B (NMDA2), and NR3 (NMDA3) in samples of the trigeminal subnucleus caudalis in arthritic rats treated with magnesium chloride $\left(\mathrm{MgCl}_{2}\right)$. Water $\left(\mathrm{V}\right.$; vehicle) or $\mathrm{MgCl}_{2}$ (90 mg kg${ }^{-1}$ ) was administered orally for $7 \mathrm{~d}$ (twice daily, at 12 -h intervals) before intra-articular injection of $5 \%$ carrageenan $(10 \mu \mathrm{l})$ into the left temporomandibular joint (TMJ). The expression of the NR1, NR2B, and NR3 genes was evaluated in samples of the trigeminal subnucleus caudalis region. The data are expressed as the mean \pm standard error of the mean of six rats. ${ }^{*} P<0.05$, compared with control (naive; Student's $t$-test).

guidelines were used to choose the optimal dose of magnesium, we nonetheless attempted to avoid toxic effects by not exceeding plasma magnesium levels of $3 \mathrm{mM}$ (13). We also considered whether supplementation with oral magnesium can cause magnesium to reach the central nervous system. Previous studies reported significant magnesium concentrations in cerebrospinal fluid and in the spinal cord after administration of intraperitoneal magnesium sulfate and a magnesium-enriched diet, demonstrating that magnesium is indeed able to cross the blood-brain barrier and reach central NMDA-Rs $(27,30)$. Therefore, we assumed that magnesium could play a central role in blocking NMDA-Rs and consequently in the hypernociceptive process.

In the present study, we induced hypomagnesemia (i.e. magnesium levels $<1.8 \mathrm{mg} \mathrm{dl}^{-1}$ or $\left.<0.74 \mathrm{mM}\right)(9$, 27) by administering a special diet. We also measured plasma magnesium levels and found a significant difference from baseline. The response to mechanical stimulation was investigated both before and after the induction of magnesium deficiency. Magnesium deficiency induced a hyperalgesic state. Thresholds in the magnesium-deficient group remained lower than in 

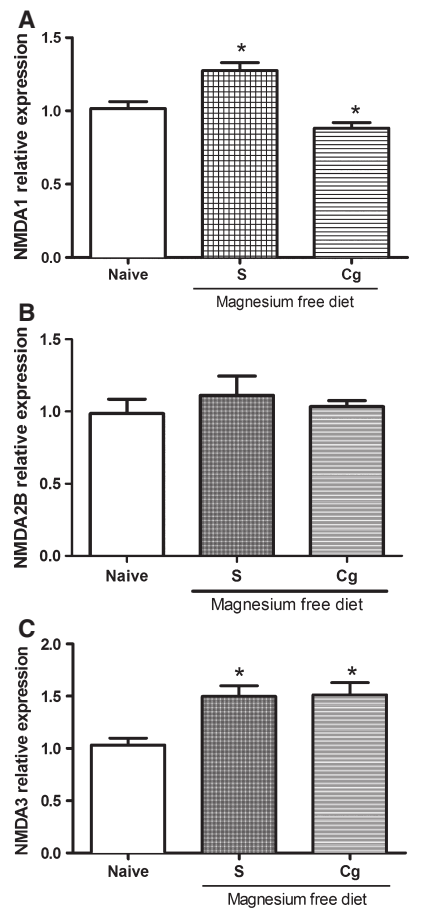

Fig. 7. Relative quantitative mRNA expression of the $N$ methyl-D-aspartate receptors (NMDA-Rs) NR1 (NMDA1), NR2B (NMDA2), and NR3 (NMDA3) in samples of the trigeminal subnucleus caudalis in arthritic rats with magnesium deficiency. Saline $(\mathrm{S})$ or $5 \%$ carrageenan $(\mathrm{Cg} ; 10 \mu \mathrm{l})$ was injected intra-articularly into the left temporomandibular joint (TMJ) in rats fed a magnesium-free diet. The naive group consisted of non-treated rats fed a normal diet. The expression of the NR1, NR2B, and NR3 genes was evaluated in samples of the trigeminal subnucleus caudalis region. The data are expressed as the mean \pm standard error of the mean (SEM) of six rats. ${ }^{*} P<0.05$, compared with control (naive; Student's $t$-test).

the normal diet group during the entire experiment. The hypernociceptive effect of magnesium deficiency was reversed by MK-801, demonstrating that NMDA-Rs play a role in this process. These results are consistent with those of previous studies $(9,10,12,27)$.

We attempted to determine whether magnesium deficiency or supplementation influences expression of $N M D A-R$ subunits. We found that expression of the NR1 subunit increased in response to treatment with $\mathrm{Cg}$, which is consistent with other work (31). We also found an increase in the level of phosphorylated NR1 in the Cg-induced arthritis group. Several studies have suggested that NR1 phosphorylation is correlated with the presence of neuropathic and inflammatory pain (22, 32, 33). Moreover, conditional deletion of NR1 mRNA reduced NMDA-mediated hyperalgesia induced by peripheral injury (34), and NR1 subunit knockout mice exhibited a reduction in hypernociception and allodynia (35).

The induction of magnesium deficiency also resulted in upregulated expression of NR1 and increased phospho-NR1 immunostaining, possibly explaining the decrease in nociceptive thresholds in rats that did not receive $\mathrm{Cg}$ treatment.
In addition to the increase in hypernociceptive behavior, downregulation of expression of the NR1 subunit occurred in the magnesium-deficiency group treated with $\mathrm{Cg}$. This may reflect a necessary adaptive response to avoid excessive neuronal excitability, glutamate-induced NMDA-R overstimulation, and an excitotoxic process that leads to cell death, all of which can be observed in many neurological conditions (3639). However, we did not observe a decrease in phospho-NR1; rather, we observed an increase of phospho-NR1 in the magnesium-depleted $\mathrm{Cg}$ group in comparison with the $\mathrm{Cg}$ group. These findings suggest that the decreased mRNA expression did not affect protein levels at this time point or the phosphorylation process.

Treatment with $\mathrm{MgCl}_{2}$ did not modify expression of NR1 mRNA but did result in a decrease of NR1 phosphorylation. A recent study demonstrated that $\mathrm{MgSO}_{4}$ supplementation reversed the increase in phospho-NR1 in diabetic mice but did not modify total NR1 expression (40).

We assessed expression of NR2 because this subunit has been directly implicated in pain perception (41-44) in response to tissue injury and TMJ injury (10). This subunit appears to be less sensitive to magnesium blockade during the potentiation of protein kinase $\mathrm{C}$ that occurs during inflammatory hyperalgesia (41).

In the present study, expression of the NR2B subunit was downregulated by treatment with $\mathrm{MgCl}_{2}$. We suggest that magnesium exerts an antinociceptive effect and downregulates expression of this subunit. Magnesium deficiency did not have any apparent effects on expression of NR2B, but induced hypernociception. This may be attributable to the absence of magnesiuminduced blockade of NMDA-Rs. Similarly to previous studies, we also observed a tendency toward upregulated expression of NR2B in Cg-induced arthritis $(15,19$, 23).

We observed an upregulation of NR3 subunit expression with magnesium deficiency and $\mathrm{MgCl}_{2}$ supplementation. To our knowledge, this is the first work that has demonstrated these findings. No study of which we are aware has related NR3 subunit expression with pain and magnesium deficiency or supplementation. The literature shows that NMDA-Rs formed with this subunit are insensitive to magnesium blockade, and that neuronal and glial cells express this type of receptor in response to injury (45-47). Additionally, when coexpressed with the NR1 and NR2 subunits, NR3 modulates NMDA-R activity by decreasing receptor conductance, calcium permeability, and magnesium sensitivity $(48,49)$.

With regard to the modulatory effect of magnesium on glutamate release, we speculate that magnesium deficiency induced by dietary deficiency upregulates the NR3 subunit through a physiological compensatory mechanism. A compensatory mechanism increases expression of NR3 mRNA, which has an inhibitory effect on NMDA-evoked glutamate currents because NR3 is neuroprotective (47). This subunit is insensitive to glutamate and also exhibits a reduced probability of 

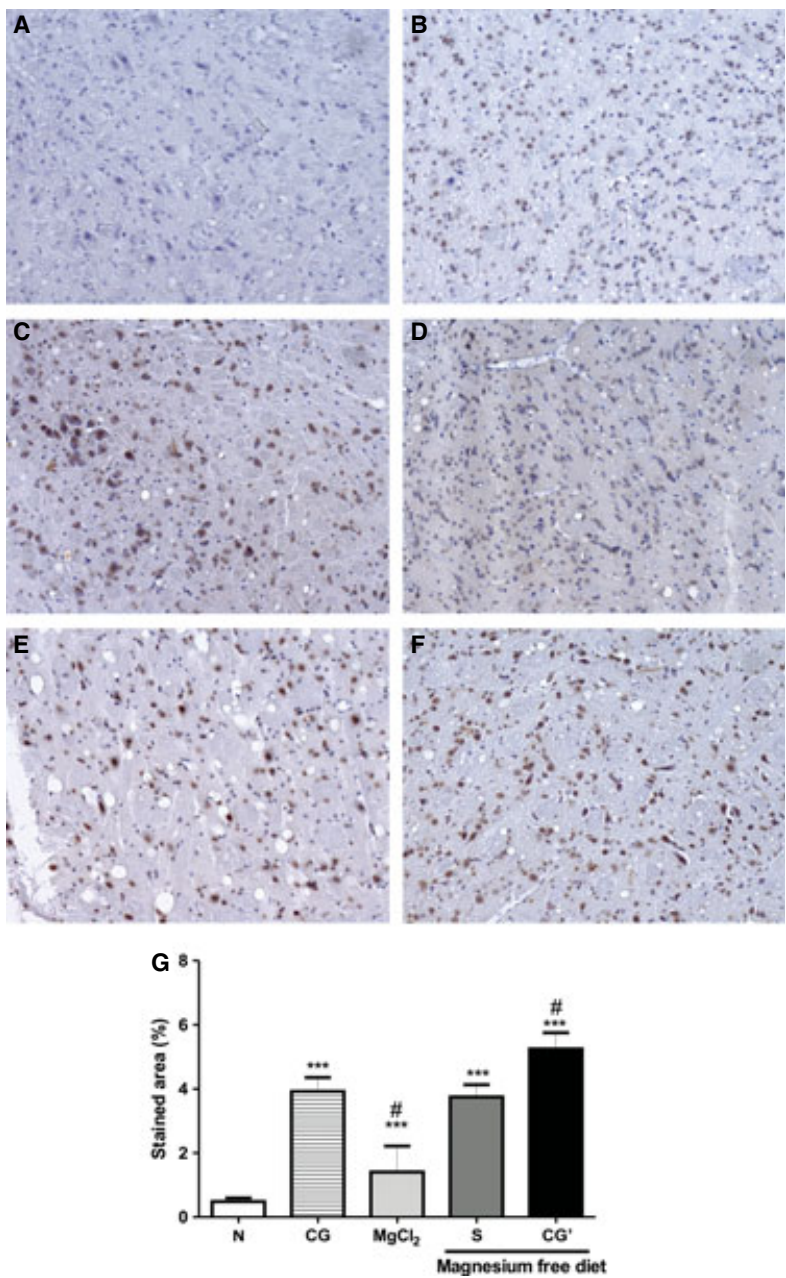

Fig. 8. Photomicrography of phosphorylated NR1 (phosphoNR1) immunostaining in the trigeminal subnucleus caudalis in rats. (A) The negative control (absence of primary antibody) shows a lack of staining. (B) Naïve (N) rats show weak staining. (C) Rats subjected to carrageenan-induced temporomandibular joint (TMJ) arthritis (CG) show strong staining. (D) Rats subjected to carrageenan-induced TMJ arthritis and treated with magnesium chloride $\left(\mathrm{MgCl}_{2}\right)\left(90 \mathrm{mg} \mathrm{kg}^{-1}\right.$ for $7 \mathrm{~d})$ show reduced staining. (E) Magnesium-deficient rats (S) show strong staining. (F) Magnesium-deficient rats subjected to carrageenan-induced TMJ arthritis ( $\mathrm{CG}^{\prime}$ ) show strong staining. $200 \times$ magnification. (G) Bars show the area of positive phospho-NR1 staining, expressed as mean percentage \pm standard error of the mean $(n=4)$. ${ }^{* * *} P<0.001$, compared with the naive group $(\mathrm{N}) ;{ }^{\#} P<0.05$, compared with the carrageenan group (CG) (ANOvA followed by Bonferroni's post-hoc test).

single-channel opening and longer mean opening times (46, 50-52). Some work has demonstrated that mice which lack the NR3 subunit exhibit an increase in NMDA currents and spine density (47, 50). Other authors have associated magnesium deficiency with neuroprotective events in the brain (53).

The present results showed that $\mathrm{MgCl}_{2}$ supplementation increased expression of the NR3 subunit and decreased expression of the NR2B subunit, which makes neuronal cells express more NR1/NR3 type of receptors. This type of NMDA-R is insensitive to magnesium blockade and decreases synaptic activity. Moreover, $\mathrm{MgCl}_{2}$ decreased the formation of phospho-NR1, indicating inhibition of NMDA-R function.

In summary, we found that NMDA-Rs play an important role in TMJ inflammatory hypernociception and that magnesium has an antinociceptive effect in this condition. Furthermore, physiological magnesium levels are important for the maintenance of nociceptive thresholds in the trigeminal pathway because magnesium deficiency induces a hypernociceptive state. Both magnesium supplementation and deficiency influence expression of $N M D A-R$ subunit mRNA in the subnucleus caudalis of the trigeminal sensory complex. The increase in expression of the NR3 subunit and decrease in expression of the NR2B subunit may explain this modulatory effect of magnesium on nociceptive thresholds, but further investigations should be performed to confirm these observations. The present results may lead to a better understanding of central processing in the nociceptive trigeminal pathway and the development of new approaches to treat orofacial pain with a TMJ origin.

Acknowledgements - The authors thank Maria Silvandira França Pinheiro of the Department of Physiology and Pharmacology and Maria do Socorro França Monte of the Department of Morphology, Faculty of Medicine, Federal University of Ceará, Brazil, for technical assistance and Michael Arends for English correction. This work was supported by grants from Fundação Cearense de Apoio ao Desenvolvimento Científico e Tecnológico (FUNCAP) and Coordenação de Aperfeiçoamento de Pessoal de Nível Superior (CAPES).

Conflicts of interest - The authors declare that they have no conflicts of interest.

\section{References}

1. Dahlstrom L, Carlsson GE. Temporomandibular disorders and oral health-related quality of life. A systematic review. Acta Odontol Scand 2010; 68: 80-85.

2. Hargreaves KM. Orofacial pain. Pain 2011; 152: S25-S32.

3. Britton NF, Chaplain MA, Skevington SM. The role of N-methyl- D-aspartate (NMDA) receptors in wind-up: a mathematical model. IMA J Math App Med Biol 1996; 13: 193-205.

4. Chen J, Lee CT, Errico SL, Becker KG, Freed WJ. Increases in expression of 14-3-3 eta and 14-3-3 zeta transcripts during neuroprotection induced by delta 9-tetrahydrocannabinol in AF5 cells. $J$ Neurosci Res 2007; 85: 1724-1733.

5. Dickenson AH. A cure for wind-up: NMDA receptor antagonists as potential analgesics. Trends in Pharmacol Sci 1990; 11: $307-309$.

6. EIDE PK. Wind-up and the NMDA receptor complex from a clinical perspective. Eur J Pain 2000; 4: 5-15.

7. Parada CA, Luccarini P, Woda A. Effect of an NMDA receptor antagonist on the wind-up of neurons in the trigeminal oralis subnucleus. Brain Res 1997; 761: 313-320.

8. REN K. Wind-up and the NMDA receptor: from animal studies to humans. Pain 1994; 59: 157-158.

9. Begon S, Pickering G, Eschalier A, Mazur A, Rayssiguier Y, Dubray C. Role of spinal NMDA receptors, protein kinase $\mathrm{C}$ and nitric oxide synthase in the hyperalgesia induced by magnesium deficiency in rats. $B r J$ Pharmacol 2001; 134: $1227-1236$. 
10. Bereiter DA, Bereiter DF. Morphine and NMDA receptor antagonism reduce c-fos expression in spinal trigeminal nucleus produced by acute injury to the TMJ region. Pain 2000; 85: 65-77.

11. Cairns Be, Svensson P, Wang K, Hupfeld S, GravenNielsen T, Sessle BJ, Berde CB, Arendt-Nielsen L. Activation of peripheral NMDA receptors contributes to human pain and rat afferent discharges evoked by injection of glutamate into the masseter muscle. J Neurophysiol 2003; 90: 2098-2105.

12. Davar G, Hama A, Deykin A, Vos B, Maciewicz R. MK801 blocks the development of thermal hyperalgesia in a rat model of experimental painful neuropathy. Brain Res 1991; 553: $327-330$

13. Felsby S, Nielsen J, Arendt-Nielsen L, Jensen TS. NMdA receptor blockade in chronic neurophatic pain: a comparison of ketamine and magnesium chloride. Pain 1996; 64: 283291.

14. Ivanusic JJ, Beaini D, Hatch RJ, Staikopoulos V, Sessle BJ, Jennings EA. Peripheral N-methyl-d-aspartate receptors contribute to mechanical hypersensitivity in a rat model of inflammatory temporomandibular joint pain. Eur $J$ Pain 2011; 15: 179-185.

15. Liu Y, Zhang J. Recent development in NMDA receptors. Chin Med J 2000; 113: 948-956.

16. Petrenko AB, Yamakura $\mathrm{T}, \mathrm{Baba} \mathrm{H}$, Shimoji $\mathrm{K}$. The role of N-methyl-D-aspartate (NMDA) receptors in pain: a review. Anesth Analg 2003; 97: 1108-1116.

17. Li J, McRoberts JA, Nie J, Ennes HS, Mayer EA. Electrophysiological characterization of N-methyl-D-aspartate receptors in rat dorsal root ganglia neurons. Pain 2004; 109: 443-452.

18. JenKINSON DH. The nature of the antagonism between calcium and magnesium ions at the neuromuscular junction. J Physiol 1957; 138: 434-444.

19. Johnson JW, Ascher P. Voltage-dependent block by intracellular $\mathrm{Mg}^{2+}$ of N-methyl-D-aspartate-activated channels. Biophys $J$ 1990; 57: 1085-1090.

20. Ren K, Dubner R. Central nervous system plasticity and persistent pain. J Orofac Pain 1999; 13: 155-163.

21. Cull-Candy SG, Leszkiewicz DN. Role of distinct NMDA receptor subtypes at central synapses. Sci STKE 2004; 2004: re16.

22. Michaelis EK. Molecular biology of glutamate receptors in the central nervous system and their role in excitotoxicity, oxidative stress and aging. Prog Neurobiol 1998; 54: 369-415.

23. Miki K, Zhou QQ, Guo W, Guan Y, Terayama R, Dubner $\mathrm{R}$, REN K. Changes in gene expression and neuronal phenotype in brain stem pain modulatory circuitry after inflammation. J Neurophysiol 2002; 87: 750-760.

24. Denadai-Souza A, Camargo Ll, Ribela mT, Keeble Je, Costa SK, Muscara MN. Participation of peripheral tachykinin NK1 receptors in the carrageenan-induced inflammation of the rat temporomandibular joint. Eur J Pain 2009; 13: 812-819.

25. Paxinos G, Huang XF. Atlas of the human brainstem. San Diego: Academic Press, 1995.

26. Pfaffl MW. A new mathematical model for relative quantification in realtime time RT-PCR. Nucleic Acids Res 2001; 29: e45.

27. Alloui A, Begon S, Chassaing C, Eschalier A, Gueux E, RAYsSiguier Y. Does $\mathrm{Mg}^{2+}$ deficiency induce a long-term sensitization of the central nociceptive pathways? Eur J Pharmacol 2003; 469: 65-69.

28. Feria M, Abad F, Sanchez A, Abreu P. Magnesium sulphate injected subcutaneously suppresses autotomy in peripherally deafferented rats. Pain 1993; 53: 287-293.

29. Begon S, Pickering G, Eschalier A, Dubray C. Magnesium and MK-801 have a similar effect in two experimental models of neuropathic pain. Brain Res 2000; 887: 436-439.

30. Hallak M. Effect of parenteral magnesium sulfate administration on excitatory amino acid receptors in the rat brain. Magnes Res 1998; 11: 117-131.
31. Wang S, Lim G, Mao J, Sung B, Mao J. Regulation of the trigeminal NR1 subunit expression induced by inflammation of the temporomandibular joint region in rats. Pain 2009; 141: 97-103.

32. Raymond La, Tingley WG, Blackstone CD, Roche KW, Huganir RL. Glutamate receptor modulation by protein phosphorylation. J Physiol Paris 1994; 88: 181-192.

33. Ultenius C, Linderoth B, Meyerson BA, Wallin J. Spinal NMDA receptor phosphorylation correlates with the presence of neuropathic signs following peripheral nerve injury in the rat. Neurosci Lett 2006; 399: 85-90.

34. Da Silva LF, Walder RY, Davidson BL, Wilson SP, Sluka KA. Changes in expression of NMDA-NR1 receptor subunits in the rostral ventromedial medulla modulate pain behaviors. Pain 2010; 151: 155-161.

35. South SM, Kohno T, Kaspar BK, Hegarty D, Vissel B, Drake CT, Ohata M, Jenab S, Sailer AW, Malkmus S, Masuyama T, Horner P, Bogulavsky J, Gage FH, Yaksh TL, Woolf CJ, Heinemann SF, Inturrisi CE. A conditional deletion of the NR1 subunit of the NMDA receptor in adult spinal cord dorsal horn reduces NMDA currents and injuryinduced pain. $J$ Neurosci 2003; 23: 5031-5040.

36. Kus L, Sanderson JJ, Beitz AJ. N-methyl-D-aspartate R1 messenger RNA and [125I] MK-801 binding decrease in rat spinal cord after unilateral hind paw inflammation. Neuroscience 1995; 68: 159-165.

37. Mu Y, Otsuka T, Horton AC, Scott DB, Ehlers MD. Activity-dependent mRNA splicing controls ER export and synaptic delivery of NMDA receptors. Neuron 2003; 40: 581-594.

38. Waters KA, MaCHaAlani R. NMDA receptors in the developing brain and effects of noxious insults. Neurosignals 2004; 13: $162-174$

39. Yokoyama H, Kuroiwa H, Kasahara J, Araki T. Neuropharmacological approach against MPTP (1-methyl-4phenyl-1,2,3,6- tetrahydropyridine)-induced mouse model of Parkinson's disease. Acta Neurobiol Exp 2011; 71: 269-280.

40. Rondon LJ, Privat AM, Daulhac L, Davin N, Mazur A, Fialip J, Eschalier A, Courteix C. Magnesium attenuates chronic hypersensitivity and spinal cord NMDA receptor phosphorylation in a rat model of diabetic neuropathic pain. J Physiol 2010; 588: 4205-4215.

41. Fu L, TANG R, BaO N, Wang J, Ma H. Ketamine and propofol in combination induce neuroapoptosis and down-regulate the expression of $\mathrm{N}$ - methyl-D-aspartate glutamate receptor NR2B subunit in rat forebrain culture. Pharmazie 2011; 66: $771-776$.

42. Loftis JM, Janowsky A. The N-methyl-D-aspartate receptor subunit NR2B: localization, functional properties, regulation, and clinical implications. Pharmacol Ther 2003; 97: $55-85$.

43. MA QP, Hargreaves RJ. Localization of N-methyl-D-aspartate NR2B subunits on primary sensory neurons that give rise to small-caliber sciatic nerve fibers in rats. Neuroscience 2000; 101: 699-707.

44. Mihara Y, Egashira N, Sada H, Kawashiri T, Ushio S, Yano T, Ikesue H, Oishi R. Involvement of spinal NR2Bcontaining NMDA receptors in oxaliplatin-induced mechanical allodynia in rats. Mol Pain 2011; 7: 8 .

45. Cavara NA, Orth A, Hollmann M. Effects of NR1 splicing on NR1/NR3B-type excitatory glycine receptors. BMC Neurosci 2009; 10: 32.

46. Henson MA, Roberts AC, Perez-Otano I, Philpot BD. Influence of the NR3A subunit on NMDA receptor functions. Prog Neurobiol 2010; 91: 23-37.

47. Nakanishi N, Tu S, Shin Y, Cui J, Kurokawa T, Zhang D, Chen HS, Tong G, Lipton SA. Neuroprotection by the NR3A subunit of the NMDA receptor. $J$ Neurosci 2009; 29: $5260-5265$

48. Matsuda K, Kamiya Y, Matsuda S, Yuzaki M. Cloning and characterization of a novel NMDA receptor subunit NR3B: a dominant subunit that reduces calcium permeability. Brain Res Mol Brain Res 2002; 100: 43-52.

49. Nishi M, Hinds H, Lu HP, Kawata M, Hayashi Y. Motoneuron-specific expression of NR3B, a novel NMDA-type 
glutamate receptor subunit that works in a dominant-negative manner. J Neurosci 2001; 21: RC185.

50. Das S, Sasaki YF, Rothe T, Premkumar LS, Takasu M, Crandall J, Dikkes P, Conner DA, Rayudu PV, Cheung W, Chen HS, Lipton SA, Nakanishi N. Increased NMDA current and spine density in mice lacking the NMDA receptor subunit NR3A. Nature 1998; 393: 377-381.

51. Perez-Otano I, Schulteis CT, Contractor A, Lipton SA, Trimmer JS, Sucher NJ, Heinemann SF. Assembly with the NR1 subunit is required for surface expression of NR3A-containing NMDA receptors. $J$ Neurosci 2001; 21 $1228-1237$

52. Sasaki YF, Rothe T, Premkumar LS, Das S, Cui J, Talant ova MV, Wong HK, Gong X, Chan SF, Zhang D, NaKantSHI N, Sucher NJ, Lipton SA. Characterization and comparison of the NR3A subunit of the NMDA receptor in recombinant systems and primary cortical neurons. $J$ Neurophysiol 2002; 87: 2052-2063.

53. German-Fattal M, Lecerf F, Sabbagh F, Maurois P, DurLACH J, BAC P. Neuroprotective gene profile in the brain of magnesium-deficient mice. Biomed Pharmacother 2008; 62: 2064-2072.

\section{Supporting Information}

Additional Supporting Information may be found in the online version of this article:

Fig. S1. Photomicrographs of temporomandibular joints from experimental groups. 